\title{
HUBUNGAN LITERASI DIGITAL DENGAN KUALITAS PENGGUNAAN E-RESOURCES
}

\author{
Ervina Nurjanah $^{1 *}$, Agus Rusmana², Andri Yanto ${ }^{3}$ \\ ${ }^{123}$ Program Studi Ilmu Perpustakaan, Fakultas Ilmu Komunikasi, Universitas Padjadjaran, \\ Jalan Raya Bandung-Sumedang Km 21 Sumedang, Jawa Barat, Indonesia \\ ${ }^{*}$ Korespondensi: ervina.nurjanah19@gmail.com
}

\begin{abstract}
[Title: Correlation Between Digital Literacy and The Quality of E-resources Utilities] This research is about correlation between digital literacy and the quality of e-resources utilities. Digital literacy in this research was based on digital literacy conceptualization stated by David Bawden (2008) that is consists of four main dimensions, i.e basic competencies, information background knowledge, digital literacy main competence, and attitude and perspective. The purpose of this research is to know the relation between the digital literacy with the quality of the use of $e$ resources on student Faculty of Dentistry Universitas Padjadjaran. Method used in this research is quantitative with correlational approach, that is to find out if there are correlation between two or more variables, and in what level. The research subject are 90 students of Faculty of Dentistry Universitas Padjadjaran year 2014 who were selected by simple random technique. The research's results show that digital literacy basic competency was significant low correlation with the quality of e-resources utility, whereas information background knowledge has significant moderate correlation with the quality of e-resources utility. Meanwhile, digital literacy main competency has significant moderate correlation with the quality of e-resources utility, and the information user's attitude and perspective are significantly correlated moderately with the quality of e-resources utility. Overall, it is concluded that digital literacy has a very high correlation with the quality of e-resources utility, in other word, digital literacy has been a key to determine the high quality of the use of e-resources.
\end{abstract}

Keywords: digital literacy; e-resources; library science

\begin{abstract}
Abstrak
Penelitian ini membahas tentang hubungan literasi digital dengan kualitas penggunaan e-resources. Literasi digital dalam penelitian ini didasarkan pada konseptualisasi literasi digital yang terdiri dari empat dimensi utama yaitu kemampuan dasar, latar belakang pengetahuan informasi, kompetensi utama literasi digital, serta sikap dan perspektif. Adapun tujuan dari penelitian ini adalah Tujuan dari penelitian ini adalah untuk mengetahui hubungan antara literasi digital dengan kualitas penggunaan e-resources pada mahasiswa Fakultas Kedokteran Gigi Universitas Padjadjaran. Penelitian ini menggunakan metode kuantitatif dengan pendekatan korelasional yaitu untuk mengetahui ada dan tidaknya hubungan antara dua variabel atau lebih dan seberapa tingkat hubungannya. Penelitian ini dilakukan kepada 90 orang mahasiswa Fakultas Kedokteran Gigi angkatan 2014 Universitas Padjadjaran yang dipilih dengan menggunakan teknik simple random sampling. Hasil penelitian menunjukkan bahwa kemampuan dasar literasi digital memiliki hubungan yang signifikan dengan kualitas penggunaan e-resources, dengan kategori low correlation. Latar belakang pengetahuan informasi memiliki hubungan yang signifikan dengan kualitas penggunaan e-resources, dengan kategori moderate correlation. Kompetensi utama literasi digital memiliki hubungan yang signifikan dengan kualitas penggunaan e-resources, dengan kategori moderate correlation. Sikap dan perspektif pengguna informasi memiliki hubungan yang signifikan dengan kualitas penggunaan e-resources, dengan kategori moderate correlation. Secara keseluruhan literasi digital memiliki hubungan yang signifikan dengan kualitas penggunaan e-resources, dengan kategori very high correlation, artinya literasi digital menjadi faktor yang sangat menentukan terhadap tingginya kualitas penggunaan e-resources.
\end{abstract}

Kata kunci: literasi digital; e-resources; ilmu perpustakaan 


\section{Pendahuluan}

Seiring dengan perkembangan teknologi informasi dan komunikasi, kini internet telah menjadi sumber informasi yang populer dikalangan mahasiswa karena mampu menawarkan akses informasi yang mudah, cepat, dan dalam jumlah yang hampir tidak terbatas. Berdasarkan hasil riset yang dilakukan oleh Asosiasi Penyelenggara Jasa Internet Indonesia (APJII) dan Pusat Kajian Komunikasi Universitas Indonesia (Puskakom UI) yang dipublikasikan pada bulan Maret 2015 menyatakan bahwa mahasiswa berada di posisi ke-2 sebagai pengakses internet terbesar di Indonesia yaitu sebanyak $18 \%$ atau sekitar 1.585.800 dari total pengguna internet Indonesia yang berjumlah 88,1 juta dan sebanyak 29,3\% dari pengakses internet dari kalangan mahasiswa tersebut menyatakan alasan mereka menggunakan internet adalah untuk kepentingan pendidikan (Asosiasi Penyedia Jasa Internet Indonesia, 2015: 13).

Kemudahan akses dan melimpahnya informasi yang dapat diperoleh melalui internet, disisi lain justru mengakibatkan mahasiswa menjadi kurang selektif dalam memilih sumber informasi yang akan digunakannya. Berdasarkan World Summit on The Information Society (WSIS) Declaration yang menyatakan bahwa "where everyone can create, access, utilize and share information and knowledge, enabling individuals, communities and peoples to achieve their full potential in promoting their sustainable development and improving their quality of life... (WSIS Declaration 2003, Paragraph 1). Setiap orang dapat mencipta, mengakses, menggunakan dan berbagi atau membagikan informasi dan pengetahuan, dengan konsekuensi bahwa setiap orang haruslah dapat menghadapi dan menguasai informasi dengan benar (Sukaesih and Rohman, 2013: 62). Akan tetapi kemudahan untuk membagikan dan mengakses informasi digital melalui internet,justru mengakibatkan banyaknya informasi yang tidak dapat dipertanggungjawabkan beredar luas melalui berbagai media publikasi digital seperti blog atau wordpress yang tidak mencantumkan kejelasan sumber informasi, dan ternyata masih banyak mahasiswa yang menggunakan informasi tersebut sebagai rujukan tugas akademiknya padahal di internet juga tersedia sumber informasi digital seperti electronic resources (eresources) yang bersifat open access yang dapat diakses dengan menggunakan komputer personal, mainframe, atau perangkat mobile dari jarak jauh melalui internet ataupun intranet yang terdiri dari berbagai jenis seperti e-book, e-journal, database full text, database indexing dan abstracting, e-images, e-audio, video, dan lain-lain (Surachman, 2012: 2). Untuk menanggulangi kondisi tersebut maka dibutuhkan keterampilan khusus yang dikenal dengan istilah pola literasi. Lebih lanjut Miftah (2016) menyatakan bahwa pola literasi merupakan bentuk atau struktur yang terjadi pada suatu keadaan yang terus menerus yang dilakukan oleh sekelompok orang dalam melakukan serangkaian pembelajaran mulai dari tahapan menerima dan membaca hingga tahapan menciptakan. Salah satu jenis literasi yang berkaitan dengan kemampuan khusus dalam menggunakan berbagai informasi dalam format digital adalah literasi digital. 
Gagasan mengenai literasi digital mulai dipopulerkan oleh Gilster pada tahun 1997 sebagaimana dikutip dalam Belshaw (2011) menyatakan bahwa "Digital literacy is the ability to understand and use information in multiple formats from a wide variety of sources when it is presented via computers". Menurut Gilster literasi digital merupakan kemampuan untuk memahami dan menggunakan informasi dalam berbagai format yang berasal dari berbagai sumber digital yang ditampilkan melalui komputer (Belshaw, 2011: 98). Dalam perkembangan selanjutnya, Bawden (2008) mengemukakan sebuah pemahaman baru mengenai literasi digital yang dikembangkan berdasarkan pada konsep literasi komputer dan literasi informasi. Dalam konsep barunya tersebut, Bawden membangun konseptualisasi literasi digital yang terdiri dari empat komponen utama yaitu kemampuan dasar literasi digital (underpinning),latar belakang pengetahuan informasi (background knowledge), kompetensi utama literasi digital (central competencies), serta sikap dan perspektif informasi (attitudes and perspective)(Bawden, 2008: 29-30).

Saat ini, penelitian yang berkaitan dengan literasi digital dan e-resources banyak dilakukan pada bidang ilmu informasi, bidang pendidikan, teknologi informasi dan komunikasi, serta pada beberapa bidang lainnya tergantung pada konteks dari penelitian yang akan dilakukan. Adapun dalam penelitian ini, mengangkat literasi digital dan penggunaan e-resources dalam konteks ilmu informasi, dimana literasi digital yang dibahas memiliki fokus utama pada bidang informasi yang berkaitan dengan kajian mengenai cara menemukan, mengevaluasi, dan menggunakan informasi terutama yang berasal dari sumber informasi elektronik (e-resources).

Salah satu penelitian mengenai literasi digital pernah dilakukan oleh Murray dan Perez (2014) berdasarkan hasil assessment literasi digital yang dilakukan terhadap mahasiswa tingkat akhir pada universitas regional di Amerika Serikat, menyatakan bahwa pemahaman mengenai literasi digital tidak dapat disamakan dengan tingkat paparan dan interaksi mahasiswa dengan teknologi digital pada kesehariannya, hasil assessment literasi digital menunjukkan hanya 12\% dari mahasiswa yang mampu menjawab sekitar $80 \%$ jawaban dengan benar. Hal ini menunjukkan bahwa meskipun pada dasarnya mahasiswa telah sering berinteraksi dengan teknologi digital namun bukan berarti mereka memiliki pemahaman yang baik mengenai literasi digital, sehingga dibutuhkan adanya pengembangan strategi peningkatan literasi digital bagi mahasiswa yang bersifat koheren, inklusif dan holistik (Murray and Perez, 2014: 95).

Penelitian tentang literasi digital juga pernah dilakukan oleh Mery Yanti (2016) dengan judul penelitian Determinants of Student Digital Literacy: The case of Sriwijaya University. Penelitian ini bertujuan untuk menganalisis kontribusi kesenjangan digital terhadap tingkat literasi digital di kalangan mahasiswa Universitas Brawijaya. Hasil penelitian ini menyatakan bahwa literasi digital dipengaruhi oleh perbedaan kepemilikan, biaya komunikasi, dan faktor usia pertama kali menggunakan perangkat TIK 
(komputer, laptop dan lain-lain), keberadaan hubungan ini semakin menjelaskan urgensi untuk mengelola interaksi antara anak-anak dengan perangkat TIK baik melalui pendidikan formal, informal, dan nonformal. Selain itu, hasil penelitian ini juga menyatakan pentingnya untuk mendorong para pembuat kebijakan dalam membuat patokan dan instrumen penilaian kompetensi TIK minimal yang harus dimiliki mahasiswa yang mirip Test of English as a Foreign Language (TOEFL) atau Tes Potensi Akademik (TPA) (Yanti, 2016).

Selanjutnya penelitian mengenai e-resources pernah dilakukan oleh Fauziah (2016) dalam studi kasus dengan judul "Dampak Implementasi Kebijakan Akses E-resources di Perpustakaan Perguruan Tinggi Delima Jakarta”, yang dilakukan terhadap mahasiswa akhir yang sedang mengerjakan skripsi atau tesis, menunjukkan hasil bahwa pemanfaatan e-resources di perpustakaan perguruan tinggi terbilang cukup tinggi karena adanya suatu kebutuhan akan informasi dan pengetahuan terkini sebagai pendukung pembelajaran dan penelitian. Akan tetapi dalam pemanfaatannya perlu dilakukan peninjauan kembali terhadap kebijakan akses yang diterapkan perpustakaan guna memenuhi hak-hak pemustaka untuk memanfaatkan e-resources yang tersedia (Fauziah, 2011).

Penelitian sebelumnya masing-masing mengkaji mengenai literasi digital dan e-resources dari berbagai aspek yang berbeda, namun penelitian-penelitian tersebut tidak membahas mengenai bagaimana hubungan keterampilan literasi digital dengan kemampuan seseorang untuk memilih informasi yang akan digunakan dari sekian banyak sumber informasi elektronik (e-resources) yang ditampilkan dari hasil pencarian melalui internet berdasarkan pada evaluasi terhadap kualitas penggunaan e-resources terutama untuk kebutuhan penyelesaian tugas akademik. Berdasarkan hal tersebut, maka dari penelitian-penelitian sebelumnya belum dapat diketahui apakah terdapat hubungan antara literasi digital dengan kualitas penggunaan e-resources, sehingga fokus dari penelitian ini adalah untuk melihat bagaimana hubungan antara literasi digital dengan kualitas penggunaan e-resources.

Dalam penelitian ini, telah dilakukan survei prapenelitian terhadap 80 orang mahasiswa yang telah memperoleh pembelajaran pada mata kuliah literasi informasi dan literasi digital, hasil yang diperoleh menujukan bahwa sebanyak 68\% mahasiswa seringkali merasa kesulitan untuk melakukan akses $e$ resources sehingga lebih sering menggunakan informasi dari blog atau wordpress untuk dijadikan sebagai sumber rujukan dalam menyelesaikan tugas akademiknya. Kondisi yang berbeda terjadi pada mahasiswa Fakultas Kedokteran Gigi yang tidak memperoleh pembelajaran mengenai literasi informasi dan literasi digital secara khusus namun menunjukkan tingkat akses e-resources yang cukup tinggi yaitu mencapai 16.803 kali akses berdasarkan pada data statistik jumlah pengakses e-resources Perpustakaan Center of Information Scientific Resources and Library (CISRAL) Universitas Padjadjaran tahun 2014. Kondisi ini cukup menarik untuk diteliti, guna mengetahui apakah terdapat hubungan antara literasi digital dengan kualitas penggunaan e-resources. 
Berdasarkan kondisi tersebut, maka rumusan masalah yang diajukan dalam penelitian ini adalah bagaimana hubungan literasi digital dengan kualitas penggunaan e-resources pada mahasiswa fakultas Kedokteran Gigi Universitas Padjadjaran. Dalam penelitian ini juga dilakukan uji hipotesis terhadap lima aspek hubungan yaitu hubugan kemampuan dasar literasi digital dengan kualitas penggunaan $e$-resources, hubungan latar belakang pengetahuan informasi dengan kualitas penggunaan e-resources, hubungan kompetensi utama literasi digital dengan kualitas penggunaan e-resources, hubungan sikap dan perspektif penggunaan informasi dengan kualitas penggunaan e-resources, dan hubungan literasi digital dengan kualitas penggunaan e-resources.

Hasil penelitian ini dapat dijadikan sebagai bahan pertimbangan bagi perpustakaan perguruan tinggi pada institusi terkait untuk memutuskan apakah diperlukan untuk membuat program khusus guna meningkatkan literasi digital pada mahasiswa agar mampu mengakses dan menggunakan e-resources yang berkualitas secara baik dan benar.

\section{Metode Penelitian}

Penelitian ini menggunakan analisis korelasional dengan pendekatan penelitian kuantitatif. Penelitian dengan pendekatan kuantitatif menekankan pada keluasan informasi sehingga metode ini cocok untuk digunakan pada populasi yang luas. Data yang diteliti dalam penelitian kuantitatif merupakan data sampel yang diambil dari populasi dengan menggunakan teknik probability sampling sehingga dalam penelitian kuantitatif ini lebih mengandalkan pada angka-angka berupa skor yang diperoleh dari kuesioner. Teknik sampling peluang (probability sampling) digunakan sebagai cara untuk mendapatkan sampel yang representatif (Prijana, Winoto \& Yanto, 2016). Data yang dipelajari merupakan sampel yang diambil dari populasi yang telah ditentukan sehingga ditemukan kejadian-kejadian relatif, dan hubunganhubungan antar variabel. Berdasarkan data dari sampel tersebut, dapat dibuat generalisasi berupa kesimpulan sampel yang diberlakukan juga pada populasi di mana sampel tersebut diperoleh (Sugiyono, 2013).

Teknik analisis data diarahkan pada pengujian hipotesis yang diajukan serta untuk menjawab rumusan masalah. Pada penelitian ini digunakan analisis korelasi. Uji koefisien korelasi dimaksudkan agar dapat menentukan keeratan hubungan dua variabel yang diteliti. Uji korelasi dimaksudkan untuk melihat hubungan dari dua hasil pengukuran atau dua variabel yang diteliti (Riduwan \& Sunarto, 2012).

Penelitian ini dilakukan pada mahasiswa Fakultas Kedokteran Gigi Universitas Padjadjaran. Responden dalam penelitian ini dipilih menggunakan teknik probability sampling dengan metode simple random sampling menggunakan tabel angka random. Diperoleh sebanyak 90 orang sample dari total 115 populasi yang dihitung menggunakan rumus Slovin. Teknik pengumpulan data yang dilakukan adalah studi kepustakaan, penyebaran kuesioner kepada responden terpilih, dan wawancara kepada pihak-pihak tertentu yang dianggap memiliki informasi yang dibutuhkan untuk kepentingan penelitian. 


\section{Hasil dan Pembahasan}

Berdasarkan hasil penelitian, diketahui bahwa tingkat literasi digital mahasiswa Fakultas Kedokteran Gigi Universitas Padjadjaran berdasarkan konseptualisasi literasi digital dari Bawden (2008) yang terdiri dari empat komponen utama yaitu kemampuan dasar literasi digital, latar belakang pengetahuan informasi, kompetensi utama literasi digital, serta sikap dan perspektif pengguna informasi (Bawden, 2008: 29-30), adalah sebagai berikut:

Tigkat Literasi Digital Mahasiswa l'akultas Kedohteran Gigi Universitas Padjadjaran Burdusurkan pada Kons:plualisasi Liturasi Digilal dani Bawdun

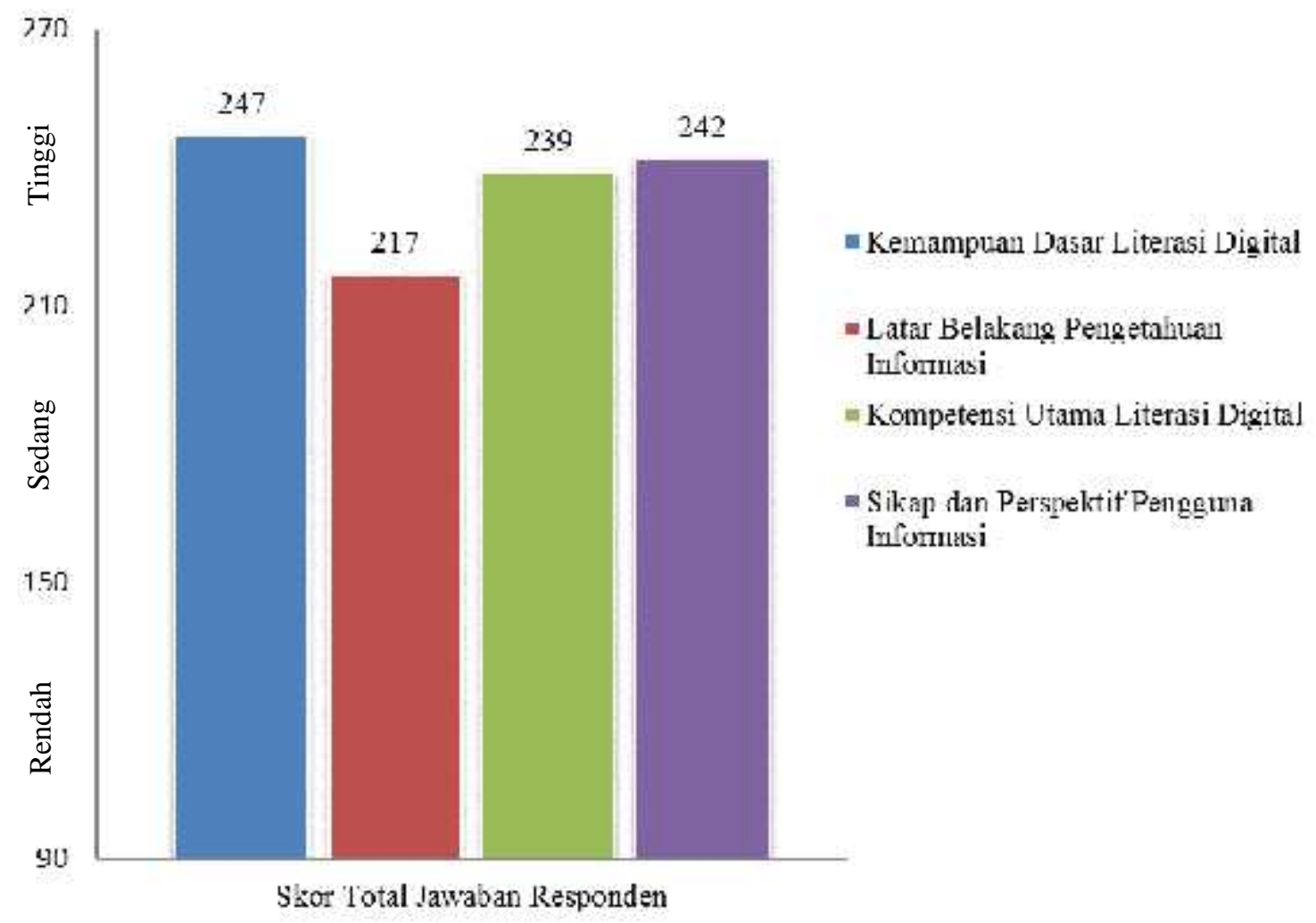

1. Kemampuan Dasar Literasi Digital

Kemampuan dasar literasi digital yang dimaksud terdiri dari keterampilan dasar literasi yang mencakup kemampuan untuk membaca, menulis, memahami simbol untuk merepresentasikan bahasa dan melakukan perhitungan angka, dan keterampilan dasar literasi komputer yang mencakup kemampuan menggunakan hardware dan software komputer. Berdasarkan hasil penelitian diketahui bahwa mahasiswa Fakultas Kedokteran Gigi memiliki tingkat kemampuan dasar literasi digital yang tinggi.

Tingginya tingkat kemampuan dasar literasi digital pada mahasiswa Fakultas Kedokteran Gigi Universitas Padjadjaran dapat dikatakan sebagai kondisi yang wajar, karena pada dasarnya kemampuan dasar literasi dan kemampuan dasar literasi komputer telah diajarkan pada jenjang pendidikan menengah 
sebelum mereka mengenyam pendidikan di perguruan tinggi sesuai dengan Peraturan Menteri Pendidikan dan Kebudayaan Republik Indonesia Nomor 4 Tahun 2015 pasal 1 ayat (5) yang menyatakan bahwa peserta didik SMP/SMA/SMK berdasarkan kurikulum 2013 mendapat layanan bimbingan teknologi informasi dan komunikasi/keterampilan komputer dan pengelolaan informasi (TIK/KKPI) dari guru TIK/KKPI (Menteri Pendidikan dan Kebudayaan Republik Indonesia, 2015: 2).

\section{Latar Belakang Pengetahuan Informasi}

Latar belakang pengetahuan informasi yang dimaksud adalah menyangkut pemahaman yang diperlukan mengenai bagaimana informasi digital dan non digital dibuat dan dikomunikasikan serta bagaimana sumber informasi yang dihasilkannya. Hasil penelitian menunjukkan bahwa mahasiswa Fakultas Kedokteran Gigi Universitas Padjadjaran memiliki latar belakang pengetahuan informasi yang tinggi karena didukung oleh metode pembelajaran yang diterapkan pada program studi dimana mereka belajar yang mana telah menerapkan student active learning dengan metode pembelajaran problem based learning, dimana mahasiswa didorong untuk mampu mengembangkan diri, mampu menyelesaikan permasalahan sendiri dan mampu untuk terus belajar sendiri sepanjang hayat (self-long life learner).Serta didukung pula oleh kelengkapan koleksi perpustakaan yang mampu menyediakan sumber informasi yang memadai dan pustakawan yang dapat memberikan layanan informasi yang mumpuni dengan dukungan berbagai program user education/library orientation/library instruction. Program tersebut juga dapat dikembangkan lagi menjadi sebuah program literasi informasi di perguruan tinggi. Hal ini sesuai dengan yang dikemukakan oleh Agustina (2013) bahwa program usereducation/ library instruction penting diajarkan dijenjang pendidikan dasar dan pendidikan lanjutan serta Perguruan Tinggi melalui program pendidikan literasi informasi.

Selain itu, adanya pembelajaran LSIT (Learning Skill Information Technology) juga menjadi salah satu faktor pendorong tingginya latar belakang pengetahuan informasi pada mahasiswa Fakultas Kedokteran Gigi Universitas Padjadjaran, pembelajaran LSIT bertujuan untuk memberikan pengetahuan mengenai keterampilan belajar dan penguasaan teknologi informasi untuk mahasiswa sebelum mengikuti proses pembelajaran pada blok lainnya. Pada blok LSIT mahasiswa diberikan materi terkait dengan proses pendidikan di Fakultas Kedokteran Gigi Universitas Padjadjaran, proses tutorial, teknik membaca buku teks dan jurnal, teknik diskusi, teknik menulis karya ilmiah, moral akademik, penelusuran pustaka ilmiah dan pengelolaan referensi berbasis teknologi informasi, pemanfaatan teknologi dan perangkat serta sumber digital untuk pembelajaran(Fakultas Kedokteran Gigi UNPAD, 2013: 31).

\section{Kompetensi Utama Literasi Digital}

Kompetensi utama literasi digital yang dimaksud dalam penelitian ini meliputi pemahaman format informasi digital dan non digital, kemampuan untuk menciptakan dan mengkomunikasikan informasi digital, kemampuan evaluasi informasi, kemampuan perakitan pengetahuan, keterampilan literasi 
informasi dan keterampilan literasi media. Dari hasil penelitian yang dilakukan, maka diketahui bahwa mahasiswa Fakultas Kedokteran Gigi Universitas Padjadjaran memiliki tingkat kompetensi utama literasi digital yang tinggi. Salah satu hal yang menjadi faktor pendorong tingginya pemahaman tentang kompetensi utama literasi digital pada mahasiswa Fakultas Kedokteran Gigi Universitas Padjadjaran adalah adanya standar kompetensi yang telah ditetapkan oleh Konsil Kedokteran Indonesia bahwasanya salah satu kemampuan utama yang harus dimiliki oleh seorang dokter gigi adalah mampu menganalisis kesahihan informasi dan memanfaatkan teknologi informasi kesehatan gigi mulut secara ilmiah, efektif, sistematis dan komprehensif dalam mengambil keputusan. Mampu melakukan komunikasi, edukasi, dan penyampaian informasi secara efektif dan bertanggung jawab baik secara lisan maupun tulisan dengan pasien semua usia, keluarga atau pendamping pasien serta masyarakat, teman sejawat dan profesi kesehatan lain yang terkait (“Standar Kompetensi Dokter Gigi Indonesia,” 2015).

Meskipun sifatnya lebih spesifik terkait dengan bidang kesehatan namun dengan adanya standar kompetensi tersebut maka mahasiswa kedokteran gigi dituntut untuk dapat menggunakan teknologi informasi dan komunikasi dengan baik untuk memperoleh informasi yang benar/sahih, serta dapat memanfaatkannya secara ilmiah, efektif, sistematis dan komprehensif sebagai bahan pertimbangan dalam pengambilan keputusan, serta dapat mengkomunikasikannya secara efektif dan bertanggungjawab. Hal tersebutlah yang menjadi salah satu faktor pendorong mahasiswa Fakultas Kedokteran Gigi Universitas Padjadjaran memiliki kompetensi utama literasi digital yang tinggi.

4. Sikap dan Perspektif Pengguna Informasi

Sikap dan perspektif pengguna informasi yang dimaksud dalam penelitian ini mencakup kemampuan belajar mandiri, pemahaman mengenai penggunaan informasi dan pemahaman mengenai hak cipta. Hasil penelitian menunjukkan bahwa mahasiswa Fakultas Kedokteran Gigi Universitas Padjadjaran memiliki sikap dan perspektif pengguna informasi yang tinggi diakibatkan oleh adanya etika akademik yang harus ditaati oleh seluruh civitas akademika pada suatu institusi pendidikan.

Menurut Soeparto et al. dalam bukunya Etik dan Hukum di Bidang Kesehatan: Etik Akademik (2006) sebagaimana dikutip oleh Gabriella et al. (2012) menyatakan bahwa salah satu point penting yang harus diperhatikan oleh mahasiswa dalam menyusun tugas akademiknya, adalah "Seorang insan akademik dilarang mengakui hasil karya orang lain sebagai hasil karya pribadinya sendiri (plagiat) ataupun memalsukan hasil sebuah penelitian" (Gabriella et al., 2012: 52). Sikap dan perspektif penggunaan informasi yang tinggi pada mahasiswa Fakultas Kedokteran Gigi merupakan kondisi yang wajar terjadi, karena pada dasarnya setiap tugas akademik yang dibuat oleh mahasiswa haruslah dapat dipertanggungjawabkan baik dari segi isi ataupun orisinalitas ide yang yang dibuat dan harus mencantumkan sumber dari setiap kutipan atau rujukan yang digunakan sebagai upaya menghindari praktek plagiarisme. 
Selain itu, menurut Rusmana (2016) dalam virtual community juga memiliki aturan dan norma interaksi yang diberlakukan untuk mengatur tindakan dan interaksi agar tidak terjadi pelanggaran norma yang berlaku (Rusmana, 2016: 189). Hal ini menunjukkan bahwa dalam interaksi yang dilakukan menggunakan teknologi informasi melalui internet juga diberlakukan atauran dan norma yang hampir sama dengan proses interaksi secara langsung sehingga penting untuk diperhatikan sikap dan perilaku dalam berinteraksi dan menggunakan informasi yang diperoleh melalui media digital seperti internet.

Selanjutnya, berkaitan dengan kualitas penggunaan e-resources terdapat lima komponen utama yang diteliti berdasarkan CRAAP Test (2010) yang terdiri dari pemahaman kemutakhiran informasi (currency), pemahaman kesesuaian informasi (relevancy), pemahaman kepemilikan sumber informasi (authority), pemahaman ketepatan informasi (accuracy), pemahaman tujuan informasi (purpose)(Meriam Library State University,2010). Maka hasil penelitian menunjukkan bahwa tingkat kualitas penggunaan $e$ resources pada mahasiswa Fakultas Kedokteran Gigi Universitas Padjadjaran adalah sebagai berikut:

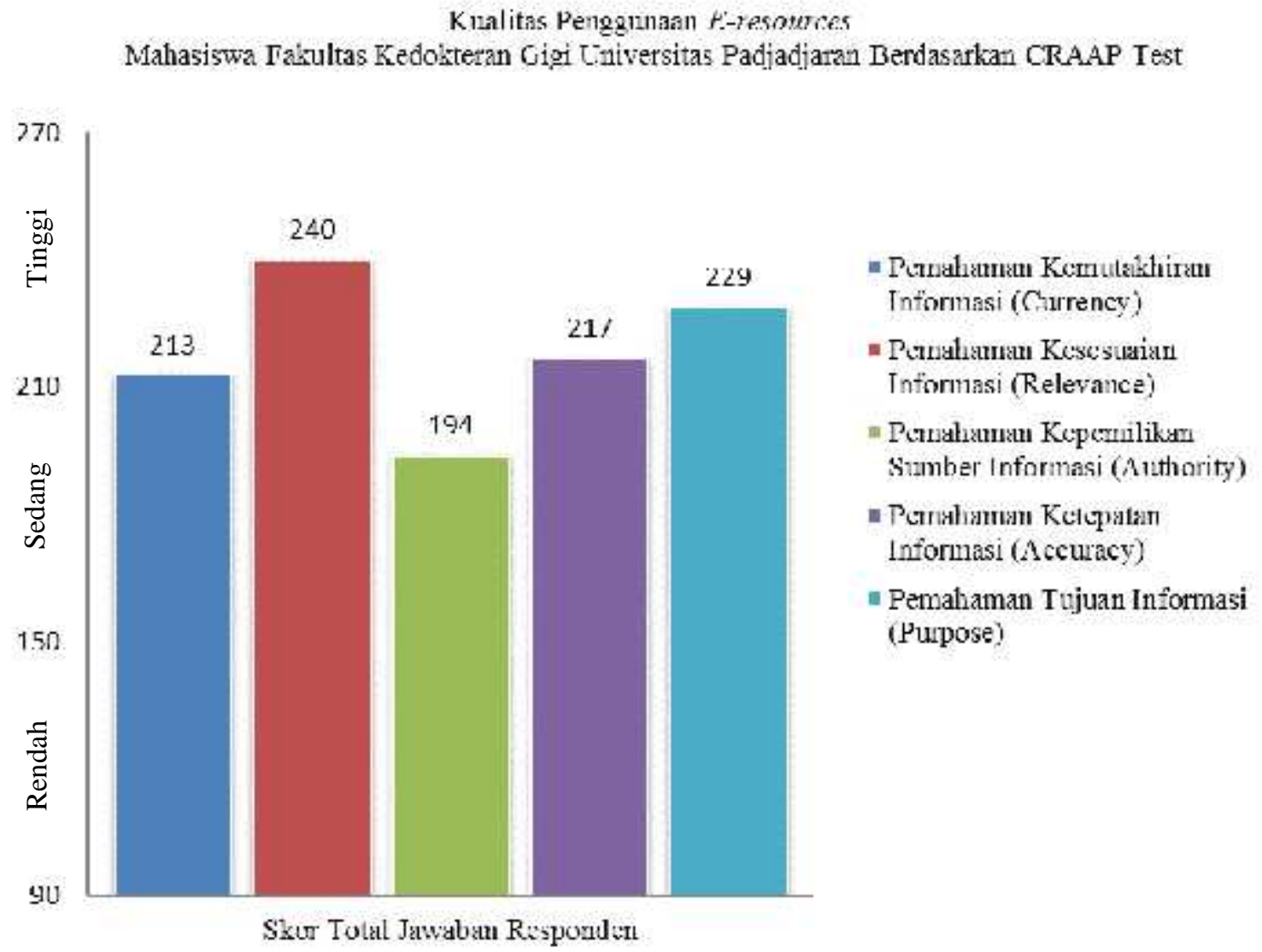

1. Pemahaman Kemutakhiran Informasi (Currency)

Tingkat pemahaman tentang kemutakhiran informasi yang tinggi pada mahasiswa Fakultas Kedokteran Gigi Universitas Padjadjaran merupakan salah satu dampak dari kebutuhan mahasiswa untuk 
terus mengikuti perkembangan terbaru pada bidang yang mereka tekuni karena kebutuhan untuk mengetahui bagaimana perkembangan permasalahan di lapangan dengan tinjauan teoritis yang terus dikembangkan sehingga dibutuhkan informasi yang mutakhir dan aktual.

Salah satu artikel yang ditulis Elliot Emanuel (1975) pada Canadian Association Medical Journal menyatakan bahwa literatur bidang kedokteran memiliki tingkat keusangan yang diukur dengan menggunakan parameter paro hidup (half-life) hanya selama 5 tahun. Hal ini dipengaruhi oleh tingkat perkembangan penelitian pada disiplin ilmu terkait(Emanuel, 1975: 572). Artinya semakin mutakhir atau semakin up to date informasi yang digunakan akan semakin baik. Sehingga kondisi inilah yang mendorong mahasiswa Fakultas Kedokteran Gigi Universitas Padjadjaran memiliki pemahaman mengenai tingkat kemutakhiran informasi yang tinggi.

2. Pemahaman Kesesuaian Informasi (Relevance)

Seorang dokter membutuhkan informasi yang tepat dan relevan untuk menetapkan diagnosis dan pengobatan sehingga dibutuhkan proses komunikasi antara dokter dan pasien dimana pasien memberikan informasi mengenai keadaan yang dia rasakan, dan dokter berperan aktif dalam mencari informasi yang relevan. Memperoleh riwayat pasien yang akurat merupakan langkah pertama dalam menentukan etiologi pasien, dan kualitas riwayat pasien tersebut bergantung pada kemampuan dokter dalam mengkaji informasi yang relevan (Liansyah and Kurniawan, 2015: 121).

Untuk memperoleh informasi yang relevan dari pasien dan menciptakan hubungan antara dokter dan pasien yang tepat, tergantung pada kesediaan dokter dan kapasitasnya untuk berinteraksi dan beradaptasi dengan pasien yang berasal dari berbagai latar belakang budaya, pendidikan dan sosial (Zazgyva et al., 2014: 246).

Sebagai seorang calon dokter gigi, mahasiswa Fakultas Kedokteran Gigi Universitas Padjadjaran harus memiliki kemampuan untuk memilih informasi yang relevan sebagai dasar dalam menetapkan diagnosis dan penyakit pasien. Inilah yang kemudian menjadi salah satu faktor pendorong tingginya pemahaman tentang tingkat kesesuaian informasi (relevance) pada mahasiswa Fakultas Kedokteran Gigi Universitas Padjadjaran.

\section{Pemahaman Kepemilikan Sumber Informasi (Authority)}

Pada dasarnya responden dalam penelitian ini telah mengetahui pentingnya pemahaman mengenai kepemilikan sumber informasi, hal tersebut ditunjukkan dengan keseharian mereka yang telah terbiasa mencantumkan sumber informasi yang mereka kutip atau dijadikan rujukan dalam mengerjakan tugas akademiknya. Namun, yang dilakukan oleh responden baru sekedar mencantumkan sumber informasi yang mereka gunakan tetapi tidak secara mendalam mencoba untuk menggali informasi lebih detail terkait dengan penulis atau penerbit informasi yang mereka gunakan, sehingga mengakibatkan responden memiliki pemahaman tentang kepemilikan sumber informasi (authority) yang sedang. 


\section{Pemahaman Ketepatan Informasi (Accuracy)}

Salah satu hal yang menjadi faktor pendorong tingginya pemahaman tentang tingkat ketepatan informasi pada mahasiswa Fakultas Kedokteran Gigi Universitas Padjadjaran adalah adanya standar kompetensi yang telah ditetapkan oleh Konsil Kedokteran Indonesia bahwasanya salah satu kemampuan dasar yang harus dimiliki oleh seorang dokter gigi adalah kemampuan untuk menggunakan ilmu pengetahuan dan teknologi kedokteran gigi mutakhir untuk mencari dan menilai informasi yang sahih dari berbagai sumber secara professional ("Standar Kompetensi Dokter Gigi Indonesia," 2015).

Kondisi tersebut dapat menjelaskan mengapa mahasiswa Fakultas Kedokteran Gigi Universitas Padjadjaran cenderung memiliki tingkat pemahaman yang tinggi mengenai ketepatan informasi karena pada dasarnya mereka dituntut untuk dapat menganalisis kesahihan informasi dan memanfaatkan teknologi informasi secara ilmiah, efektif, sistematis dan komprehensif untuk dapat digunakan sebagai pertimbangan dalam melakukan pengambilan keputusan.

\section{Pemahaman Tujuan Informasi (Purpose)}

Pherson dan Pherson (2012) dalam bukunya yang berjudul Critical Thinking for Strategic Intelegence menyatakan bahwa melakukan evaluasi mengenai tujuan sebuah situs dalam mempublikasikan informasi dapat membantu untuk menilai konten informasi yang disajikannya, apakah dimaksudkan untuk memberikan informasi, instruksi, penjelasan, mempengaruhi, atau membujuk seseorang untuk mengambil tindakan. Membedakan opini dan informasi yang terverifikasi guna mengidentifikasi apakah informasi yang disajikan merupakan fakta, opini atau propaganda(Pherson and Pherson, 2012: 113).

Selain itu, dalam artikel yang berjudul Evaluating Healt Information yang dipublikasikan oleh UCSF Medical Center, menyatakan bahwa jika tujuan informasi yang utama adalah untuk menjual produk, kemungkinan akan terdapat unsur kepentingan dimana produsen akan cenderung untuk mencegah penyajian informasi yang mengakibatkan kurangnya minat pembeli terhadap produk tersebut. Jika demikian, maka perlu dipertimbangkan kembali untuk menggunakan informasi tersebut dan perlu mencari informasi tambahan dari sumber lain yang lebih netral ("Evaluating Health Information," 2002).

Dalam hal ini jelas terlihat pentingnya mengetahui tujuan dari informasi yang ditulis atau dipublikasikan agar informasi yang digunakan sesuai dengan kebutuhan serta tidak dicampuri oleh unsur kepentingan pihak lain. Terutama untuk informasi yang digunakan dalam bidang kedokteran yang memerlukan informasi yang akurat, relevan, netral dan objektif. Kondisi inilah yang mendorong mahasiswa Fakultas Kedokteran Gigi Universitas Padjadjaran memiliki tingkat pemahaman tentang tujuan informasi (purpose) yang tinggi. 
Secara keseluruh dari penelitian yang telah dilakukan, diperoleh hasil bahwa mahasiswa Fakultas Kedokteran Gigi Universitas Padjadjaran memiliki literasi digital dan kualitas penggunaan e-resources yang tinggi, dengan skor total jawaban responden sebagai berikut:

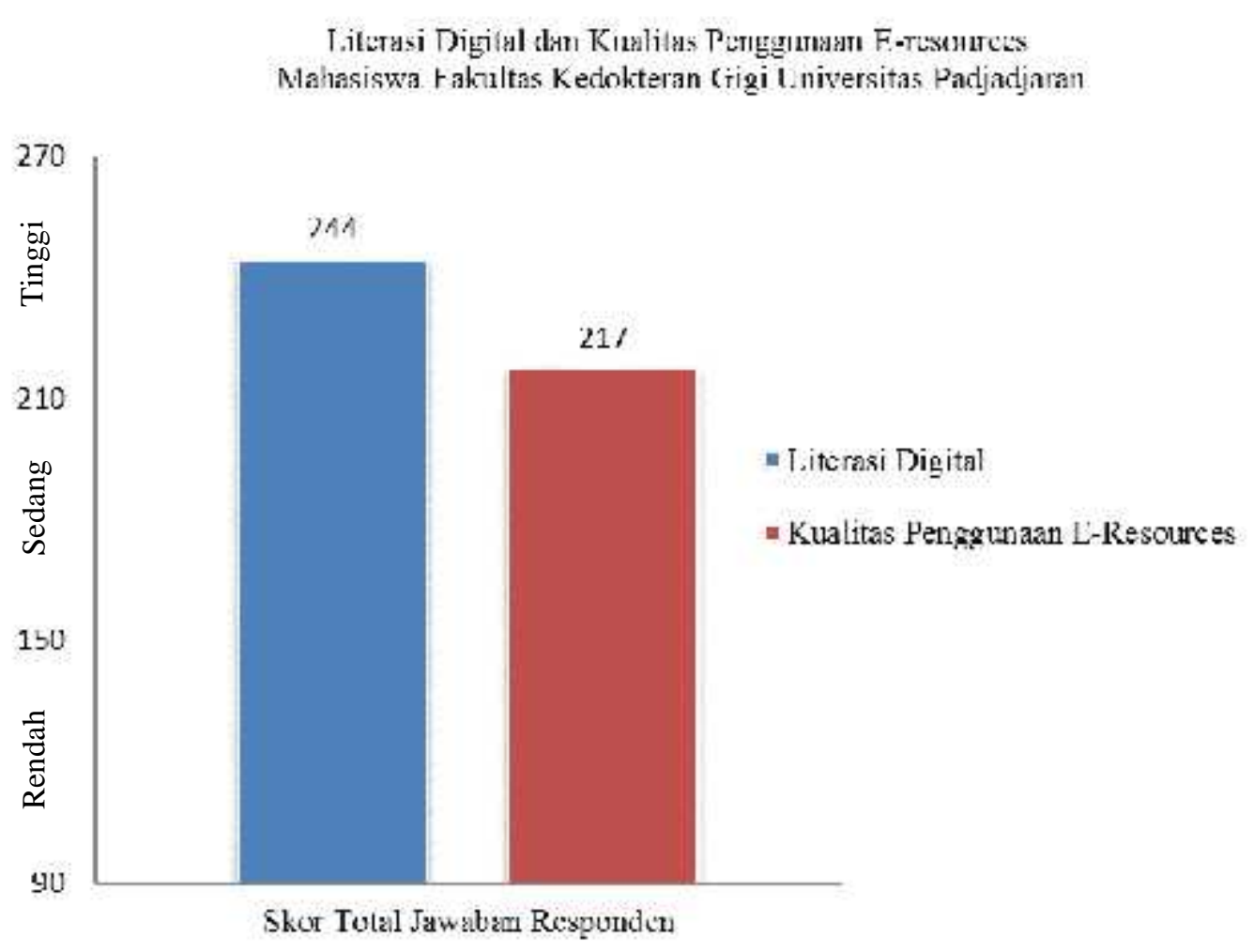

American Library Association Office for Information Technology Policy's Digital Literacy Task Force dalam Cordell (2013) menyatakan bahwa seseorang dapat dikatakan memiliki keterampilan literasi digital apabila memiliki beragam keterampilan kognitif dan teknis yang diperlukan untuk menemukan, memahami, mengevaluasi membuat dan mengkomunikasikan informasi digital dalam berbagai format; mampu menggunakan beragam teknologi secara tepat dan efektif untuk mencari dan menemukan informasi, menafsirkan hasil pencarian dan menilai kualitas informasi yang diperoleh; memahami hubungan antara teknologi, pembelajaran sepanjang hayat, privasi pribadi, dan penata layanan informasi yang tepat; menggunakan keterampilan dan teknologi tepat guna dalam berkomunikasi dan berkolaborasi dengan rekan sejawat, kolega, keluarga, dan masyarakat umum; serta mampu menggunakan seluruh keterampilan tersebut untuk berpartisipasi aktif dalam masyarakat dan komunitas (Cordell, 2013: 179).

Salah satu faktor pendukung tingginya literasi digital pada mahasiswa Fakultas Kedokteran Gigi Universitas Padjadjaran adalah adanya pembelajaran LSIT (Learning Skill Information Technology) yaitu blok yang bertujuan untuk memberikan pengetahuan mengenai keterampilan belajar dan penguasaan teknologi informasi untuk mahasiswa sebelum mengikuti proses pembelajaran pada blok lainnya. Pada blok LSIT mahasiswa diberikan materi terkait dengan proses pendidikan di Fakultas Kedokteran Gigi 
Universitas Padjadjaran, proses tutorial, teknik membaca buku teks dan jurnal, teknik diskusi, teknik menulis karya ilmiah, moral akademik, penelusuran pustaka ilmiah dan pengelolaan referensi berbasis teknologi informasi, pemanfaatan teknologi dan perangkat serta sumber digital untuk pembelajaran.

Selain itu, Profesi dokter gigi memiliki standar kompetensi tersendiri yang telah ditetapkan oleh Konsil Kedokteran Indonesia bahwasanya salah satu kemampuan utama yang harus dimiliki oleh seorang dokter gigi adalah mampu menganalisis kesahihan informasi dan memanfaatkan teknologi informasi kesehatan gigi mulut secara ilmiah, efektif, sistematis dan komprehensif dalam mengambil keputusan. Mampu melakukan komunikasi, edukasi, dan penyampaian informasi secara efektif dan bertanggung jawab baik secara lisan maupun tulisan dengan pasien semua usia, keluarga atau pendamping pasien serta masyarakat, teman sejawat dan profesi kesehatan lain yang terkait ("Standar Kompetensi Dokter Gigi Indonesia," 2015). Standar kompetensi tersebut menjadi salah satu faktor pendorong tingginya tingkat literasi digital pada mahasiswa Fakultas Kedokteran Gigi, dimana mahasiswa dituntut untuk dapat menggunakan teknologi informasi dan komunikasi guna memperoleh informasi yang sahih secara ilmiah untuk digunakan sebagai bahan pertimbangan dalam pengambilan keputusan.

Faktor lainnya yang mengakibatkan tingginya tingkat literasi digital pada mahasiswa kedokteran gigi juga dapat dipahami sebagai salah satu dampak dari pesatnya perkembangan teknologi informasi dan komunikasi dimana kini untuk mempermudah dan memperluas jangkauan pelayanan kesehatan salah satunya dikembangkan konsep telemedicine, sebagai upaya untuk memanfaatkan perkembangan teknologi informasi dan komunikasi di bidang kedokteran. Hal inilah yang kemudian menuntut mahasiswa kedokteran gigi untuk dapat memahami dan menggunakan teknologi digital dengan baik dan benar.

Konsep telemedicine pada dasarnya berisi kegiatan pengolahan, diseminasi, penyimpanan, pencarian, dan pertukaran informasi untuk tujuan mempromosikan kesehatan, mencegah penyakit, mengobati sakit, mengelola penyakit kronis, melindungi kesehatan dan keselamatan masyarakat dengan memanfaatkan teknologi informasi dan komunikasi. Telemedicine terdiri dari kolaborasi sistem jaringan kesehatan, fasilitas, dan organisasi kesehatan yang didedikasikan untuk tujuan tersebut (Bashshur et al., 2009: 601).

Selanjutnya, salah satu faktor yang secara tidak langsung berkaitan dengan tingginya tingkat kualitas penggunaa e-resources pada mahasiswa Fakultas Kedokteran Gigi adalah mahalnya buku buku materi untuk kedokteran gigi sehingga mendorong mereka untuk mencari alternatif lain selain book material untuk bahan belajar dan referensi tugas akademik, dan salah satunya adalah dengan menggunakan e-book atau e-journal. Sebagaimana dikutip dalam majalah dJatinangor edisi 34, Nadya Laras mahasiswi Fakultas Kedokteran Gigi (FKG) Universitas Padjadjaran mengungkapkan bahwa e-book sangatlah berguna bagi dirinya dan benar-benar menjadi solusi untuk mengatasi mahalnya buku-buku materi FKG ("Yang Muda Membajak," 2012: 28). 
Wilson dalam Yusup \& Subekti (2010) menyatakan bahwa dalam melakukan pencarian informasinya individu akan berinteraksi atau menggunakan sistem pencarian manual melalui media tekstual atau menggunakan media berbasis komputer (Yusup and Subekti, 2010).

E-book dan e-journal merupakan salah satu jenis e-resources yang dapat diakses dan ditampilkan dengan menggunakan media berbasis komputer yang dijadikan sebagai alternatif pilihan oleh mahasiswa Fakultas Kedokteran Gigi selain dari informasi dalam media tekstual seperti buku. Untuk dapat melakukan akses terhadap $e$-book atau $e$-journal tersebut mendorong mereka untuk mencari tahu secara mandiri penyedia e-book atau open acces journal gratis di internet, ataupun dengan mencari informasi di perpustakaan untuk dapat memperoleh petunjuk akses e-journal dan e-book yang sudah dilanggan oleh perpustakaan Unpad. Sehingga dalam hal ini perpustakaan dan pustakawan juga memiliki peran dalam mendukung tingginya kualitas penggunaan e-resources pada mahasiswa terutama dalam memberikan layanan dan pengarahan mengenai bagaimana melakukan akses informasi dari sumber-sumber terpercaya baik berupa book material maupun non book material terutama untuk akses $e$-journal dan $e$-book yang telah dilanggan oleh perpustakaan universitas. Dengan demikian, maka kebutuhan untuk memperoleh informasi dari sumber terpercaya, akurat, relevan dan sesuai dengan kebutuhan bahan belajar dan bahan referensi dalam menyelesaikan tugas akademiknya merupakan salah satu faktor pendorong yang mengakibatkan mahasiswa Fakultas Kedokteran Gigi Universitas Padjadjaran memiliki tingkat kualitas penggunaan e-resources yang tinggi.

Selanjutnya, berdasarkan hasil uji hipotesis yang telah dilakukan terhadap lima aspek hubungan yang diajukan dalam penelitian ini, diperoleh hasil sebagai berikut:

1. Hubungan Kemampuan Dasar Literasi Digital dengan Kualitas Penggunaan E-resources

Terdapat hubungan yang signifikan antara kemampuan dasar literasi digital dengan kualitas penggunaan e-resources. Hasil uji korelasi dengan menggunakan metode korelasi pearson product moment menunjukkan nilai $\mathrm{r}_{\text {hitung }}=0.381$ dengan tingkat kepercayaan $95 \%(\alpha=0.05)$. Setelah ditafsirkan lebih lanjut menggunakan tabel interpretasi guilford maka dapat dikatakan bahwa hubungan antara kemampuan dasar literasi digital dengan kualitas penggunaan e-resources termasuk dalam kategori low correlation yaitu memiliki hubungan yang rendah atau hubungan yang kecil, artinya dengan kemampuan dasar literasi digital yang tinggi tidak menjamin dapat mencapai kualitas penggunaan e-esources yang tinggi pula, sebab untuk memperoleh kualitas penggunaan e-resources yang tinggi dibutuhkan keterampilan literasi digital yang sifatnya lebih kompleks. Adapun kemampuan dasar literasi digital yang dimaksud dalam sub variabel ini hanya mencakup kemampuan membaca, menulis, memahami simbol untuk merepresentasikan bahasa, melakukan perhitungan angka, dan kemampuan untuk menggunakan hardware dan software pada komputer. 
Kenton dan Blummer (2010) menyatakan bahwa literasi digital bukan hanya sekedar kemampuan untuk menggunakan perangkat lunak dan mengoperasikan perangkat digital, namun juga mencakup kemampuan lain yang lebih kompleks seperti kemampuan kognitif, motorik, sosiologi, dan emosi (Kenton and Blummer, 2010: 3).

Dengan demikian, hubungan yang rendah antara kemampuan dasar literasi digital dengan kualitas penggunaan e-resources dapat dikatakan wajar, karena untuk dapat mencapai kualitas penggunaan e-resources yang baik dibutuhkan keterampilan literasi digital yang sifatnya lebih kompleks, dan tidak hanya melibatkan kemampuan teknis namun juga pemahaman tentang informasi yang lebih mendalam.

2. Hubungan Latar Belakang Pengetahuan Informasi dengan Kualitas Penggunaan E-resources

Terdapat hubungan yang signifikan antara latar belakang pengetahuan informasi dengan kualitas penggunaan e-resources. Hasil uji korelasi dengan menggunakan metode korelasi pearson product moment nenunjukan nilai $\mathrm{r}_{\text {hitung }}=0.488$ dengan tingkat kepercayaan $95 \%(\alpha=0.05)$. Setelah ditafsirkan lebih lanjut menggunakan tabel interpretasi guilford maka dapat dikatakan bahwa hubungan antara latar belakang pengetahuan informasi dengan kualitas penggunaan e-resources termasuk dalam kategori moderate correlation yaitu memiliki hubungan yang sedang, artinya latar belakang pengetahuan informasi tidak sepenuhnya menjadi penentu tingginya kualitas penggunaan $e$-resources namun memiliki hubungan yang cukup berarti.

Latar belakang pengetahuan informasi yang dimaksud dalam sub variabel ini berkaitan dengan pemahaman tentang bagaimana format informasi digital dan non digital dibuat dan dikomunikasikan serta berbagai jenis informasi yang dihasilkannya. Latar belakang pengetahuan informasi juga berkaitan dengan pemahaman mengenai sifat sumber informasi yang dibutuhkan apakah tersedia secara online atau offline, gratis atau berbayar, dapat diakses secara bebas atau memerlukan autentikasi.

Gee, Hull, dan Lankshear (1996) sebagaimana dikutip oleh Lankshear dan Knobel (2008) menyatakan bahwa "Different types of text requires somewhat different background knowledge and somewhat different skills"(Lankshear and Knobel, 2008: 5).

Informasi yang dikemas dalam berbagai format yang berbeda membutuhkan latar belakang pengetahuan dan keterampilan yang berbeda untuk dapat memahaminya. Seperti saat seseorang menggunakan buku teks akan berbeda dengan saat seseorang menggunakan elektronik book (e-book). Pada saat menggunakan buku teks tidak dibutuhkan aplikasi atau program khusus untuk membacanya sehingga orang yang tidak memiliki pengetahuan untuk menggunakan komputer, smartphone atau jenis gadget lainnya pun tetap dapat membaca buku teks. Berbeda dengan e-book atau jenis e-resources lainnya yang membutuhkan aplikasi atau program khusus untuk bisa membacanya, sehingga seseorang 
yang akan menggunakan e-book atau jenis e-resources lainya tentu harus dapat mengoperasikan jenis gadget yang akan digunakannya sebagai media untuk membaca jenis informasi tersebut.

Perbedaan lain terletak dari cara memperoleh atau mengakses informasi. Jika buku teks dapat diperoleh di perpustakaan atau toko buku, maka berbeda dengan e-book atau jenis e-resources lainnya yang dapat diperoleh di internet atau pada penyedia e-resources tertentu. Dalam hal ini tentu dibutuhkan latar belakang pengetahuan informasi yang berbeda, jika seseorang ingin memperoleh buku teks bisa dengan hanya mengetahui judul, nama penulis, tahun terbit dan penerbit buku yang bersangkutan. Hal tersebut berbeda dengan e-resources yang membutuhkan latar belakang pengetahuan informasi yang lebih kompleks yaitu selain mengetahui judul, nama penulis, tahun terbit, nama jurnal penerbit, Uniform Resource Locator(URL) yang digunakan, serta diperlukan pengetahuan mengenai kredibilitas penulis, artikel atau jurnal yang dibuat telah melalui peer review atau proses editorial, sumber informasi yang relevan, mengetahui akses informasi yang dibutuhkan gratis atau berbayar, dapat diakses bebas atau memerlukan autentikasi.

Kondisi tersebut mengakibatkan latar belakang pengetahuan informasi dan kualitas penggunaan e-resources memiliki hubungan yang sedang atau moderate correlation karena pada dasarnya latar belakang pengetahuan informasi merupakan salah satu faktor yang dapat menentukan kualitas penggunaan e-resources. Meskipun demikian, kualitas penggunaan e-resources tidak hanya ditentukan oleh tingkat latar belakang pengetahuan informasi saja melainkan masih terdapat faktor-faktor lain yang juga ikut berpengaruh terhadap tingkat kualitas penggunaan e-resources.

3. Hubungan Kompetensi Utama Literasi Digital dengan Kualitas Penggunaan E-resources

Terdapat hubungan yang signifikan antara kompetensi utama literasi digital dengan kualitas penggunaan e-resources. Hasil uji korelasi dengan menggunakan metode korelasi pearson product moment menunjukkan nilai $\mathrm{r}_{\text {hitung }}=0.637$ dengan tingkat kepercayaan 95\% $(\alpha=0.05)$. Setelah ditafsirkan lebih lanjut menggunakan tabel interpretasi guilford maka dapat dikatakan bahwa hubungan antara kompetensi utama literasi digital dengan kualitas penggunaan e-resources termasuk dalam kategori moderate correlation atau memiliki hubungan yang sedang, artinya kompetensi utama literasi digital tidak sepenuhnya menjadi faktor penentu tingginya kualitas penggunaan e-resources namun memiliki hubungan yang cukup berarti.

Jika dilihat berdasarkan model information seeking in electronic environment yang dikembangakan oleh Marchionini (1995) sebagai sebuah model pencarian informasi yang berasal dari sumber informasi elektronik atau sumber informasi digital yang tersusun atas delapan tahapan yakni recognize and accept information problem, define and understand the problem,choose a search system, formulate a query, execute search, examine result, extract information,reflect/iterate/stop (Marchionini, 
1995: 51). Maka kompetensi utama literasi digital erat kaitannya dengan proses formulate a query, execute search, examine result, dan extract information.

Alfonzo dan Batson (2014) menyatakan bahwa, "digital literacy involves a wide range of skills including the ability to use software applications and other technologies to manage digital information, and the use of search logic such as boolean search operators, truncation symbols to search databases and search engines". Dari pernyataan tersebut, maka diketahui bahwa pada dasarnya literasi digital melibatkan berbagai keterampilan termasuk keterampilan untuk menggunakan perangkat lunak dan teknologi lainnya untuk mengelola informasi digital, serta kemampuan untuk menggunakan logika pencarian informasi seperti menggunakan boolean logic, truncation symbols untuk melakukan pencarian melalui database ataupun mesin pencari (Alfonzo and Batson, 2014: 61).

Penggunaan boolean logic ataupun truncation symbols sangat berkaitan dengan kegiatan memformulasikan queryyang mana membutuhkan kemampuan untuk memetakan kosakata dan strategi pencarian melalui interface sistem, selanjutnya dalam mengeksekusi pencarian dibutuhkan physical action untuk menjalankan sistem pencarian informasi, dalam proses memeriksa atau mengevaluasi hasil informasi dibutuhkan pemahaman mendalam tentang informasi dengan dibantu oleh metode evaluasi atau kriteria khusus yang ditetapkan guna melihat kualitas informasi yang diperoleh, dan ekstraksi informasi sebagai upaya untuk mengambil intisari dari informasi yang telah diperoleh dengan menyertakan sitasi atau data bibliografi dari sumber yang digunakan.

Sebagaimana diungkapkan oleh Bawden (2008) bahwasanya kompetensi utama (central competencies) literasi digital yaitu menyangkut dengan kemampuan untuk dapat mencari dan menggunakan informasi secara aktif, serta kemampuan untuk dapat menangani berbagai format informasi, yang terdiri dari pemahaman format digital dan non digital, menciptakan dan mengkomunikasikan informasi digital, evaluasi informasi, perakitan pengetahuan, literasi informasi, dan literasi media (Bawden, 2008). Maka pada dasarnya kompetensi utama literasi digital berkaitan dengan bagaimana cara seseorang dapat mencari dan menemukan informasi yang berkualitas dan sesuai dengan kebutuhannya dengan menggunakan kemampuan teknis dan melibatkan pengetahuan serta keterampilan yang sifatnya lebih kompleks untuk dapat mencapai kualitas penggunaan e-resources yang baik. Dengan demikian, wajar jika antara kompetensi utama literasi digital dengan kualitas penggunaan e-resources memiliki tingkat moderate correlation atau hubungan yang cukup berarti karena kompetensi utama literasi digital memegang peranan yang sangat penting dalam menentukan kualitas penggunaan $e$ resources walaupun tidak sepenuhnya kerena kualitas penggunaan e-resources juga dipengaruhi oleh faktor lain seperti sikap dan perspektif dari pengguna informasi itu sendiri. 
4. Hubungan Sikap dan Perspektif Pengguna Informasi dengan Kualitas PenggunaanE-resources

Terdapat hubungan yang signifikan antara sikap dan perspektif pengguna informasi dengan kualitas penggunaan e-resources. Hasil uji korelasi dengan menggunakan metode korelasi pearson product moment menunjukkan nilai $\mathrm{r}_{\text {hitung }}=0.554$ dengan tingkat kepercayaan $95 \%(\alpha=0.05)$. setelah ditafsirkan lebih lanjut menggunakan tabel interpretasi guilford maka dapat dikatakan bahwa hubungan antara sikap dan perspektif dengan kualitas penggunaan e-resources termasuk dalam kategori moderate correlation atau memiliki hubungan yang sedang, artinya sikap dan perspektif pengguna informasi tidak sepenuhnya menjadi faktor penentu tingginya kualitas penggunaan e-resources namun memiliki hubungan yang cukup berarti.

Sikap dan perspektif pengguna informasi dalam sub variabel ini mencakup kemampuan untuk belajar mandiri, dan pemahaman mengenai perilaku penggunaan informasi yang baik, benar, dan bijaksana. Selian itu, perspektif dan sikap pengguna informasi juga berkaitan dengan pemahaman bahwa akses informasi melalui media online yang hampir tidak terbatas pun tetap harus diikuti dengan pemahaman mengenai hak cipta, dan pemahaman mengenai etika komunikasi digital.

Martin (2006) dalam Lankshear dan Knobel (2008) menyatakan bahwa literasi digital merupakan kesadaran, sikap dan kemampuan individu untuk dapat menggunakan peralatan dan fasilitas digital dengan tepat, untuk mengidentifikasi, mengakses, mengelola, mengintegrasikan, mengevaluasi, menganalisis dan mensintesis sumber digital, membangun pengetahuan baru, membuat media ekspresi, dan berkomunikasi dengan orang lain dalam konteks kehidupan tertentu untuk memungkinkan aksi sosial yang konstruktif dan untuk merefleksikan semua proses tersebut (Lankshear and Knobel, 2008: 27).

Dari pernyataan tersebut, dapat diketahui bahwa aspek literasi digital tidak terlepas dari sikap dan kemampuan untuk terlibat dalam kehidupan sosial yang konstruktif. Yusminar (2014) mengemukakan bahwa sikap merupakan kemampuan internal yang berperan dalam mengambil tindakan yang dipengaruhi oleh penilaian akan untung dan rugi, baik atau buruk, memuaskan atau tidak, atas suatu tindakan yang dilakukannya. Sikap juga merupakan kecenderungan pembelajaran untuk dapat memilih sesuatu (Yusnimar, 2014: 40).

Berdasarkan hal tersebut, maka dapat diketahui bahwa pada dasarnya ketika seseorang memilih untuk mengakses atau menggunakan e-resources akan dipengaruhi oleh faktor sikap dan perspektif, bagaimana seorang pengguna informasi memberikan penilaian terhadap penggunaan e-resources berdasarkan pada penilaian keuntungan atau kerugian yang akan dia peroleh, dan baik atau buruk dampak yang akan dia rasakan, serta memuaskan atau tidak berdasarkan pada pemenuhan kebutuhan informasi yang dia inginkan. 
Husen dan Postlethwaite (1985) dalam Bawden (2001) menyatakan bahawa, "skills and attitudes one needs to function effectively within a given social role that directly or indirectly involves computers" (Bawden, 2001: 7). Keterampilan dan sikap merupakan salah satu hal yang dibutuhkan untuk menciptakan fungsi yang efektif dalam peran sosial yang secara langsung maupun tidak langsung melibatkan media komputer. Dalam hal ini, sikap akan menentukan bagaimana seseorang dapat menggunakan informasi dengan baik dan beretika, salah satunya dapat ditunjukan melalui sikap menghargai hak cipta dengan cara mencantumkan sitasi, daftar pustaka, atau sumber informasi yang digunakan sebagai tindakan untuk mencegah plagiarisme, dan tidak melakukan penyebaran berita atau informasi yang disinyalir mengandung unsur hoax.

Kondisi tersebut menyebabkan sikap dan perspektif pengguna informasi dengan kualitas penggunaan e-resources memiliki tingkat moderate correlation atau memiliki hubungan yang cukup berarti. Karena pada dasarnya ketika seseorang memilih untuk menggunakan sumber informasi tertentu tidak terlepas dari sikap dan perspektif dirinya terhadap hal yang bersangkutan.

5. Hubungan Literasi Digital (X) dengan Kualitas Penggunaan E-resources

terdapat hubungan yang signifikan antara literasi digital dengan kualitas penggunaan $e$-resources. Hasil uji korelasi dengan menggunakan metode korelasi pearson product moment menunjukkan nilai $\mathrm{r}_{\text {hitung }}=0.916$ dengan tingkat kepercayaan $95 \%(\alpha=0.05)$. Setelah ditafsirkan lebih lanjut menggunakan tabel interpretasi guilford maka dapat dikatakan bahwa hubungan antara literasi digital dengan kualitas penggunaan e-resources termasuk dalam kategori very high correlation yaitu memiliki hubungan yang sangat tinggi atau hubungan yang dapat dipercaya, artinya literasi digital menjadi faktor yang sangat menentukan tingginya kualitas penggunaan e-resources dan memiliki hubungan yang dapat dipercaya.

Marchionini telah mengembangkan model information seeking in electronic environment sebagai sebuah model pencarian informasi yang berasal dari sumber informasi elektronik atau sumber informasi digital yang tersusun atas delapan tahapan yakni recognize and accept information problem,define and understand the problem,choose a search system,formulate a query,execute search,examine result,extract information, reflect/iterate/stop (Marchionini, 1995). Tahapan pencarian informasi tersebut khusus digunakan pada electronic/digital environment agar diperoleh hasil pencarian informasi dengan kualitas yang baik dan sesuai dengan kebutuhan. Dalam pelaksanaannya, model pencarian yang dikemukakan oleh marchionini perlu didukung oleh keterampilan literasi digital agar proses pencarian informasi menjadi lebih efektif dan efisien, mengingat literasi digital merupakan keterampilan yang sangat kompleks yang melibatkan kemampuan teknis dan pemahaman yang lebih mendalam mengenai informasi. 
Literasi digital sebagaimana dikemukakan oleh Gilster dalam Belshaw (2011), menyatakan bahwa "Digital literacy is the ability to understand and use information in multiple formats from a wide variety of sources when it is presented via computers" (Belshaw, 2011: 98). Adapun electronic resources (e-resources) menurut Glossary AACR2 sebagaimana dikutip oleh Ginting dan Suharyanto (2012) dalam Pedoman Pengolahan Bahan Pustaka Sumber Elektronik (E-reseources), adalah bahan (data dan/atau program) yang diciptakan dengan menggunakan kode atau program komputer agar dapat dimanfaatakan dengan menggunakan piranti komputer. Untuk melakukan akses terhadap e-resources memerlukan piranti yang dapat langsung terhubung ke komputer seperti CD-ROM atau internet (Ginting and Suharyanto, 2012: 3).

Hubungan yang sangat tinggi antara literasi digital dengan kualitas penggunaan e-resources merupakan hal yang wajar, karena pada dasarnya literasi digital merupakan kemampuan untuk memahami dan menggunakan informasi dalam berbagai format yang berasal dari berbagai sumber digital yang ditampilkan melalui komputer, dan e-resources sendiri merupakan sumber informasi yang penggunaannya memerlukan perangkat komputer yang dapat diakses baik secara offline maupun online. Sehingga seseorang yang memiliki kemampuan literasi digital tentu dapat mengakses dan menggunakan e-resources. Selanjutnya, Bawden mengemukakan bahwa literasi digital terdiri dari empat dimensi utama yang harus dikuasai yaitu kemampuan dasar (underpinning), latar belakang pengetahuan informasi (background knowledge), kompetensi utama (central competencies), sikap dan perspektif(attitudes and perspectives) (Bawden, 2008: 29). Artinya keterampilan literasi digital dibangun oleh empat aspek utama yang saling berkaitan dan sifatnya kompleks.

Dalam menggunakan e-resources pun tidak boleh sembarangan, perlu diperhatikan berkaitan dengan kualitas penggunaan e-resources yang baik. Berdasarkan pada metode CRAAP test yang dikembangkan oleh Meriam Library State University at Chico, kualitas penggunaan e-resources dapat diukur berdasarkan lima komponen utama yaitu accuracy (tingkat kemutakhiran atau kebaruan informasi), relevance (tingkat kesesuaian informasi), authority (pemahaman tentang kepemilikan sumber informasi), accuracy (tingkat keakuratan atau ketepatan informasi), dan purpose (pemahaman tentang tujuan informasi) (Meriam Library State University, 2010).

Literasi digital pada dasarnya bukan hanya melibatkan kemampuan teknis, melainkan juga melibatkan keterampilan dan pengetahuan tentang informasi yang sifatnya lebih kompleks, maka seseorang yang memiliki tingkat literasi digital yang tinggi dapat dikatakan telah mampu menguasai empat dimensi utama literasi digital sebagaimana yang diungkapkan oleh Bawden, sehingga mampu untuk mencari, mengevaluasi, membuat dan mengkomunikasikan informasi dengan menggunakan teknologi digital secara efektif dan efisien. Dengan keterampilan tersebut, seseorang akan mampu menilai dan memilih e-resources berdasarkan pada kemutakhiran, kesesuaian, kepemilikan sumber informasi, 
ketepatan, dan tujuan informasi yang akan digunakan, sehingga kualitas penggunaan e-resources pun akan terpenuhi dengan baik. Dengan demikian, maka keterampilan literasi digital mememiliki hubungan yang sangat tinggi (very high correlation) dengan kualitas penggunaan $e$-resources.

\section{Simpulan}

Dari penelitian yang telah dilakukan maka diketahui bahwa mahasiswa Fakultas Kedokteran Gigi Universitas Padjadjaran memiliki keterampilan literasi digital dan kualitas penggunaan e-resources yang tinggi diakibatkan oleh berbagai faktor pendukung sehingga meskipun tidak memperoleh mata kuliah mengenai literasi informasi dan literasi digital namun mereka masih tetep dapat mencapai kategori yang tinggi dalam bidang teresebut. Berikut merupakan kesimpulan penelitian yang diperoleh berdasarkan hasil uji hipotesis yang telah dilakukan:

1. Kemampuan dasar literasi digital memiliki hubungan yang signifikan dengan kualitas penggunaan $e$ resources, dengan kategori low correlation, artinya dengan kemampuan dasar literasi digital yang tinggi tidak menjamin dapat mencapai kualitas penggunaan e-esources yang tinggi pula, sebab untuk memperoleh kualitas penggunaan e-resources yang tinggi dibutuhkan keterampilan literasi digital yang sifatnya lebih kompleks.

2. Latar belakang pengetahuan informasi memiliki hubungan yang signifikan dengan kualitas penggunaan e-resources, dengan kategori moderate correlation, artinya latar belakang pengetahuan informasi tidak sepenuhnya menjadi faktor penentu tingginya kualitas penggunaan e-resources namun memiliki hubungan yang cukup berarti.

3. Kompetensi utama literasi digital memiliki hubungan yang signifikan dengan kualitas penggunaan $e$ resources, dengan kategori moderate correlation, artinya kompetensi utama literasi digital tidak sepenuhnya menjadi faktor penentu tingginya kualitas penggunaan e-resources namun memiliki hubungan yang cukup berarti.

4. Sikap dan perspektif pengguna informasi memiliki hubungan yang signifikan dengan kualitas penggunaan e-resources, dengan kategori moderate correlation, artinya sikap dan perspektif pengguna informasi tidak sepenuhnya menjadi faktor penentu tingginya kualitas penggunaan $e$ resourcesnamun memiliki hubungan yang cukup berarti.

5. Literasi digital memiliki hubungan yang signifikan dengan kualitas penggunaan e-resources, dengan kategori very high correlation artinya literasi digital menjadi faktor yang sangat menentukan tingginya kualitas penggunaan e-resources dan memiliki hubungan yang dapat dipercaya. 


\section{Daftar Pustaka}

Alfonzo, P. \& Batson, J., 2014, Utilizing a Co-Teaching Model to Enhance Digital Literacy Instruction for Doctoral Students, International Journal of Doctoral Studies, vol. 9, pp.61-71.

Agustina, S., 2013. Pengembangan Program Membaca di Perpustakaan: Salah Satu Komponen Penting Menjadi Murid Melek Informasi (Information Literate Student). Jurnal Kajian Informasi dan Perpustakaan, 1(1), pp.107-118. doi: 10.24198/jkip.v1i1.9617

Asosiasi Penyedia Jasa Internet Indnesia, 2015, Profil Pengguna Internet Indonesia 2014, Jakarta.

Bashshur, R.L., Shannon, G.W., Krupinski, E.A., Grigsby, J., Kvedar, J.C., Weinstein, R.S., Sanders, J.H., Rheuban, K.S., Nesbitt, T.S., Alverson, D.C., Merrell, R.C., Linkous, J.D., Ferguson, A.S., Waters, R.J., Stachura, M.E., Ellis, D.G., Antoniotti, N.M., Johnston, B., Doarn, C.R., Yellowlees, P., Normandin, S. \& Tracy, J., 2009, National Telemedicine Initiatives: Essential to Healthcare Reform. Telemed, E-Health, vol. 15, pp. 600-610. doi:10.1089/tmj.2009.9960

Bawden, D., 2008, Origins and concepts of digital literacy, in: Digital Literacies: Concepts, Policies and Practices, Peter Lang Publishing, New York.

Bawden, D., 2001, Information and Digital Literacies; a Review of Concepts, Journal of Documentation, vol. 57(2), pp. 218-259.

Belshaw, D.A.J., 2011, What id “Digital Literacy”?, Durham University, United Kingdom.

Cordell, R.M., 2013, Information Literacy and Digital Literacy: Competing or Complementary?, Communications Information Literacy, vol. 7, pp.177-183.

Emanuel, E., 1975, A half-life of 5 years, Canadian Medical Association Journal, vol. 112, pp. 572.

Evaluating Health Information, 2002, UCSF Medica Centre, viewed 15 Maret 2017, from http://www.ucsfhealth.org/education/evaluating_health_information/.

Fakultas Kedokteran Gigi UNPAD, 2013, Pedoman Penyelenggaraan Pendidikan Fakultas Kedokteran Gigi Tahun Akademik 2013/2014, Universitas Padjadjaran, Jatinangor.

Gabriella, A., Saputra, A.D., Kristianto, A., Tasela, A., Nugroho, C.A., Lestari, D., Kurniawan, H., Sekarnesia, I.S. \& Salama, N., 2012, Kajian Bioetik Integritas Akademik, in: Integritas Akademi “Sekedar Kata Atau Nyata?”, Badan Penerbit Fakultas Kedokteran Universitas Indonesia, Jakarta.

Ginting, M. \& Suharyanto, 2012, Panduan Pengolahan Bahan Perpustakaan Sumber Elektronik (EResources), Perpustakaan Nasional Republik Indonesia, Jakarta.

Kenton, J. \& Blummer, B., 2010, Promoting Digital Literacy Skills: Examples from the Literature and Implications for Academic Librarians, Community and Junior College Libraries, vol. 16, pp. 84-99. doi:10.1080/02763911003688737.

Lankshear, C. \& Knobel, M., 2008, Digital Literascies - Concepts, Policies and Practices, Peter Lang, New York. 
Liansyah, T.M. \& Kurniawan, H., 2015, Pentingnya Komunikasi dalam Pelayanan Kesehatan Primer, JurnalKedokteran Syiah Kuala, vol. 15, p. 121.

Marchionini, G., 1995, Information Seeking in Electronic Environments, Cambridge University Press, Cambridge.

Menteri Pendidikan dan Kebudayaan Republik Indonesia, 2015, Peraturan Menteri Pendidikan dan Kebudayaan Republik Indonesia Nomor 4 tahun 2015.

Meriam Library State University, 2010, How do I? - Meriam Library - CSU, Chico, viewed 18 Januari 2017, form http://www.csuchico.edu/lins/how.html.

Miftah, M.N., Rizal, E. and Anwar, R.K., 2016. Pola Literasi Visual Infografer Dalam Pembuatan Informasi Grafis (Infografis). Jurnal Kajian Informasi dan Perpustakaan, 4(1), pp.87-94. doi: 10.24198/jkip.v4i1.11635

Murray, M.C. \& Perez, J., 2014, Unraveling the digital literacy paradox: How higher education fails at the fourth literacy, Issues in Informing Science and Technology, vol. 11, pp. 85-100.

Pherson, K.H. \& Pherson, R.H., 2012, Critical Thinking For Strategic Intelligence, CQ Press.

Prijana, Winoto, Y. and Yanto, A. (2016). Metode penelitian kuantitatif Ilmu Perpustakaan dan Informasi. Bandung: Unpad Press.

Riduwan, \& Sunarto, 2012, Pengantar Statistika untuk Penelitian Pendidikan, Sosial, Ekonomi, Komunikasi, dan Bisnis, Alfabeta, Bandung.

Rusmana, A., 2016. Penipuan dalam Interaksi Melalui Media Sosial (Kasus Peristiwa Penipuan melalui Media Sosial dalam Masyarakat Berjejaring). Jurnal Kajian Informasi dan Perpustakaan,3(2), pp.187-194. http://dx.doi.org/10.24198/jkip.v3i2.9994

Standar Kompetensi Dokter Gigi Indonesia, 2015, Konsil Kedokteran Gigi Indonesia, Jakarta.

Sugiyono, 2013, Metode Penelitian Kuantitatif Kualitatif dan R\&D, Alfabeta, Bandung.

Sukaesih, S. and Rohman, A.S., 2013. Literasi Informasi Pustakawan: Studi Kasus Di Universitas Padjadjaran. Jurnal Kajian Informasi dan Perpustakaan, 1(1), pp.61-72. doi:10.24198/jkip.v1i1.9612

Surachman, A., 2012, Pengembangan E-Resources: Salah Satu Upaya Membangun Perpustakaan Digital, Universitas Gajah Mada, Yogyakarta.

World Summit on the Information Society. 2003. Declaration of Principles URL: http://www.itu.int/wsis/ docs/geneva/offi cial/dop.html

Yang Muda Membajak, 2012,dJatinangor XXXIV, p. 28, viewed 11 March 2017, from https://issuu.com/suryarianto/docs/majalah34.

Yanti, M., 2016, Determinan literasi digital mahasiswa: kasus Universitas Sriwijaya [Determinants of students digital literacy: the case of Sriwijaya University]. Buletin Pos dan Telekomunikasi, vol. 14, pp. 79-94, doi:10.17933/bpostel.2016.140202. 
Yusnimar, 2014, E-Book dan Pengguna Perpustakaan Perguruan Tinggi di Jakarta, Al-Maktabah,vol. 13. Yusup, P.M. \& Subekti, P., 2010, Teori dan Praktik Penelusuran Informasi, Kencana, Jakarta.

Zazgyva, A., Zuh, S.-G., Voidăzan, S., Russu, O.M. \& Pop, T.S., 2014, Medical Students' View on Troublesome Aspects of Bedside Manner in a Multilingual Area, Procedia - Social and Behavioral Sciences,The Fourth International Conference on Adult Education, Romania, 2014, vol. 142, pp. 243-247, doi:10.1016/j.sbspro.2014.07.622. 